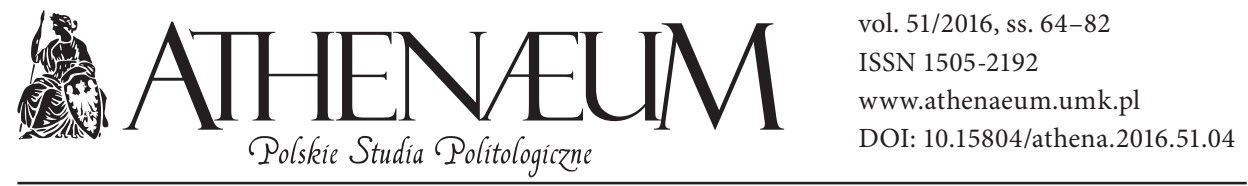

\title{
PERSPEKTYWA SIECIOWA W BADANIACH NAD PROCESEM FORMOWANIA KOALICJI GABINETOWEJ*
}

\author{
NETWORK PERSPECTIVE IN THE STUDIES ON THE PROCESS \\ OF FORMATION OF COALITION CABINET
}

Michał Banaś**, Mateusz Zieliński***

\begin{abstract}
ABSTRAKT
Jednym z podstawowych procesów w systemach parlamentarano-gabinetowych jest formowanie koalicji gabinetowej. Jego badania leżą w centrum zainteresowania politologii, a ich dalszy rozwój tworzenie nowych teorii, zastosowanie nowych narzędzi badawczych - bezpośrednio wpływa na dynamikę rozwoju całej dziedziny nauki.

W niniejszym artykule zaprezentowano metodologiczno-teoretyczne zagadnienia związane z użyciem nowej perspektywy badawczej $\mathrm{w}$ analizie wskazanego obszaru rzeczywistości politycznej. Autorzy wykazali zgodność założeń perspektywy sieciowej z istniejącą tradycją badań
\end{abstract}

\begin{abstract}
One of the basic processes in the parliamentary system is the formation of a coalition cabinet. This issue lies in the centre of political science and further development of studies devoted to this problem - the creation of new theories, application of new research tools - directly affects the dynamics of the entire field of science.

The article presents methodological and theoretical issues related to the use of a new research perspective in the analysis of the process of formation of coalition cabinets. Authors demonstrated compliance of assumption of network perspective with existing research tradition on coalition
\end{abstract}

* Treść artykułu opiera się na książce obu autorów zatytułowanej Formowanie koalicji gabinetowych w perspektywie sieciowej - studium przypadku sojuszu PO-PSL z 2007 roku, która ukazała się w 2015 r. nakładem wydawnictwa Atla2. Prace nad artykułem oraz nad wspomnianą książką zostały wykonane w ramach wewnętrznego projektu badawczego realizowanego na Wydziale Nauk Społecznych Uniwersytetu Wrocławskiego (nr projektu: 2192/M/IPol/14) i zostały sfinansowane ze środków Ministerstwa Nauki i Szkolnictwa Wyższego na prowadzenie badań naukowych lub prac rozwojowych oraz zadań z nimi związanych służących rozwojowi młodych naukowców oraz uczestników studiów doktoranckich w ramach decyzji nr 5492/E-344/M/2003.

** Uniwersytet Wrocławski, Instytut Politologii.

*** Uniwersytet Wrocławski, Instytut Politologii. 
nad koalicjami gabinetowymi, podkreślając równocześnie jej konstytutywne cechy, świadczące o oryginalności proponowanego podejścia. Przedstawiono zarówno szanse, jak i trudności związane z wykorzystaniem perspektywy sieciowej, co w konsekwencji pozwoliło odpowiedzieć na pytanie dotyczące zasadności jej zastosowania w badaniach nad procesem formowania koalicji gabinetowej.

Słowa kluczowe: koalicje gabinetowe, perspektywa sieciowa, partie polityczne cabinets. They stressed constitutive characteristics of network perspective and demonstrated originality of this approach. Authors presented both opportunities and difficulties associated with the use of a network perspective, which in turn helped to answer the question concerning the validity of its application in the study of the process of formation of coalition cabinet.

Keywords: coalition office, network perspective, political parties

\section{WSTĘP}

Perspektywa sieciowa zyskuje wielu sympatyków w badaniach społecznych. Dzieje się tak głównie za sprawą intuicyjnie rozumianej zbieżności jej podstawowych założeń z globalnymi trendami kształtującymi współczesne procesy społeczne i polityczne. Przeczucia badacza stanowią niewątpliwie ważny wskaźnik w obszarze nauk społecznych, ale przystosowanie wypracowanego zestawu narzędzi badawczych do nowej dziedziny badań wymusza ich uważną operacjonalizację, co często ujawnia problemy już na poziomie klaryfikacji podstawowych kategorii badawczych.

Perspektywa sieciowa, rozwijana głównie w socjologii, może być wykorzystana w badaniach politologicznych do eksplorowania wielu istotnych obszarów życia politycznego. Stosuje się ją m.in. w analizach funkcjonowania partii politycznych - organizacji kluczowych we współczesnych demokracjach przedstawicielskich, których podstawowym celem jest zdobycie lub utrzymanie władzy państwowej (Herbut, 2004, s. 298). Aby zrealizować ten cel, partie polityczne uczestniczą w procesie wyborczym i dążą do zdobycia jak największej liczby mandatów w parlamencie. Warto w tym miejscu jednak podkreślić, że w systemach, w których egzystencja gabinetu uzależniona jest od poparcia większości w legislatywie ${ }^{1}$,

1 Choć w podstawowym znaczeniu gabinet jest instytucją węższą niż rząd (stanowi kolegialny organ wykonawczy złożony z premiera oraz ministrów ponoszących odpowiedzialność polityczną przed parlamentem), to jednak w literaturze przedmiotu terminy te stosuje się zamiennie (por. Jednaka, 2004, s. 11-12). 
raczej rzadko zdarzają się sytuacje, w których jedno ugrupowanie wprowadza do parlamentów taką liczbę deputowanych, która pozwalałaby na samodzielne rządzenie (zob. Antoszewski, 2008, s. 348). W większości przypadków niezbędne jest rozpoczęcie przetargów koalicyjnych pomiędzy partiami posiadającymi reprezentację w legislatywie, których celem jest znalezienie wzajemnie korzystnego porozumienia i stworzenie trwałego sojuszu rządowego ${ }^{2}$. Jeśli perspektywa sieciowa wykorzystywana jest w badaniach dotyczących funkcjonowania partii politycznych, to istnieją również przesłanki, że może ona zostać zastosowana w eksploracji procesu formowania koalicji gabinetowej, która de facto tworzona jest przez te ugrupowania.

W związku z powyższymi ustaleniami celem autorów niniejszego artykułu jest rozpoznanie zasadności zastosowania perspektywy sieciowej w badaniach nad procesem formowania koalicji gabinetowej, a także możliwości i trudności z tym związanych. W trakcie rozważań autorzy zamierzają odpowiedzieć na następujące pytania badawcze: $\mathrm{w}$ jaki sposób rozwijały się badania $\mathrm{z}$ wykorzystaniem perspektywy sieciowej? Jakie są podstawowe założenia tej perspektywy? Jakie metody wykorzystuje się w badaniach $\mathrm{z}$ wykorzystaniem perspektywy sieciowej? W jaki sposób perspektywa ta wpisuje się w tradycję badań nad koalicjami gabinetowymi? Jaka jest zasadność wykorzystania perspektywy sieciowej w badaniach nad procesem formowania sojuszy rządowych? Oraz jakie możliwości i trudności wiążą się z wykorzystaniem podejścia sieciowego $\mathrm{w}$ analizie procesu tworzenia koalicji gabinetowej?

Tekst niniejszego artykułu podzielony został na pięć części, w których opisano kolejno: historię perspektywy sieciowej, jej główne założenia, metody badań sieciowych, zasadność wykorzystania perspektywy sieciowej w badaniach nad procesem formowania koalicji gabinetowych oraz możliwości i trudności wynikające $\mathrm{z}$ jej zastosowania w tym obszarze. Konkluzje z podjętych rozważań przedstawiono w zakończeniu.

Ustalenia zawarte w niniejszym artykule bezpośrednio nawiązują do treści książki obu autorów zatytułowanej Formowanie koalicji gabinetowych w perspektywie sieciowej - studium przypadku sojuszu PO-PSL z 2007 roku, która ukazała się w 2015 roku nakładem wydawnictwa Atla2. Artykuł powstał na gruncie doświadczeń obu autorów, które zdobyli dzięki wykorzystaniu perspektywy sieciowej w przeprowadzonych przez nich badaniach.

2 Zgodnie $\mathrm{z}$ nomenklaturą przyjętą w polskiej politologii w dalszych rozważaniach termin „koalicja” będziemy stosować zamiennie z terminami „sojusz” oraz „alians”. 


\section{HISTORIA PERSPEKTYWY SIECIOWEJ}

Problemy w zastosowaniu perspektywy sieciowej w politologii wynikają nie tylko z licznych niejasności na polu definicyjno-metodologicznym, ale również z jej długotrwałej ewolucji, którą umownie można podzielić na dwa okresy: wczesnych inspiracji oraz usystematyzowanych badań.

Socjologia była dziedziną nauki, w której powstała perspektywa sieciowa, dlatego rozwój tej nauki w dużej mierze determinuje współczesne znaczenie badań sieciowych. Jonathan $\mathrm{H}$. Turner opisuje rozwój teorii socjologicznych jako wielowątkowy proces postępujący w ramach wyznaczonych przez konkretne tradycje badawcze. W interesującym nas przypadku wskazuje on na istnienie powiązań pomiędzy współczesnymi teoriami podkreślającymi sieciowość zjawisk społecznych (np. szkołą strukturalizmu formalnego Georga Simmela), a takimi klasykami socjologii, jak Vilfredo Pareto, czy nawet Karol Marks (Turner, 2004, s. 335). Czasowy dystans tworzenia owych klasycznych teorii nie umniejsza znaczenia „okresu inspiracji” dla rozwoju perspektywy sieciowej - wyznaczył on dwa cele badań, które stały się drogowskazem dla przyszłych teoretyków, do których Barry Wellman zaliczył badanie znaczenia nieformalnych, niezhierarchizowanych powiązań między jednostkami oraz dążenie do eksploracji relacji społecznych, prowadzonych z matematyczną precyzją (Wellman, 1983, s. $155-156,159-160)$.

Pierwsze udane próby osiągnięcia tak zdefiniowanych celów w formie analizy sieciowych powiązań społecznych wiążą się z dwudziestoleciem międzywojennym, które wyznacza symboliczny początek okresu usystematyzowanych i świadomych badań wykorzystujących sieć jako główną kategorię analityczną, do czego w olbrzymim skrócie sprowadza się nowa perspektywa. Jednym z pierwszych badaczy okresu usystematyzowanych badań sieciowych był Jacob Levy Moreno, który w swych pracach wprowadził podstawy socjometrii oraz zastosował takie pojęcia, jak pole czy przestrzeń relacji społecznych (Scott, 2011, s. 21). Co więcej, zapoczątkował on użycie „socjogramów”, czyli diagramów obrazujących relacje społeczne w postaci sieci połączonych punktów. Procedura ta stała się najbardziej popularnym aspektem badań sieciowych, który z czasem rozwinął się w odrębną metodę zwaną analizą sieci społecznych (Social network analysis - SNA).

Rozwój metody SNA przez wielu badaczy jest utożsamiany z ogólnym rozwojem badań sieciowych, co prowadzi jednak do licznych nieporozumień na poziomie teoriopoznawczym. Dla przykładu Dominik Batorski twierdzi, 
że „(...) analiza sieci to coś więcej niż zastaw miar i narzędzi. To paradygmat i sposób podejścia do rzeczywistości społecznej" (Batorski, 2008, s. 171). Jeremy Boissevain uważa natomiast, że analiza sieci, choć nie jest nawet teorią, to posiada jednak teoretyczne implikacje (Boissevain, 1979, s. 392). Kluczowe wydaje się uznanie przyjętego w niniejszej pracy rozróżnienia pomiędzy SNA, która choć niezwykle popularna, pozostaje jedynie pojedynczą metodą badawczą, a perspektywą sieciową, która choć nie jest jasno określonym paradygmatem, to jednak wyznacza specyficzną optykę badań oraz sposób użycia poszczególnych metod, narzędzi i technik.

Takie rozumienie perspektywy sieciowej potwierdza dalszy rozwój badań sieciowych, które Frances S. Berry i inni proponują opisywać w kontekście kilku oddzielnych tradycji naukowych dotyczących różnych obszarów nauki: socjologii, zarządzania oraz politologii (Berry i in., 2004, s. 539-552).

W obszarze socjologii centrum omawianej tradycji stanowią prace wspomnianego już Simmela oraz jego kontynuatorów, a także dorobek Richarda M. Emersona badającego sieciowy wymiar wymiany społecznej. W obszarze public management do klasycznych należy zaliczyć prace takich autorów jak Gareth Morgan, twórcy koncepcji sieciowej współzależności instytucjonalnej, oraz Elinor Ostrom, badającej sieciowy wymiar kooperacji wewnątrzinstytucjonalnej. Ze względu na poruszaną tematykę na szerszą uwagę zasługuje tradycja badań politologicznych.

Podobnie jak w przypadku socjologii pionierów użycia perspektywy sieciowej w obszarze badań politologicznych należy szukać w okresie dwudziestolecia międzywojennego. Za symboliczny początek badań w świetle tej perspektywy może uchodzić praca The identification of blocs in small political bodies Stuarta Rice'a z 1927 roku (McClurg, Lazer, 2014, s. 1-4; por. Rice, 1927, s. 619-627). Rozwój badań sieciowych w politologii postępował jednak zdecydowanie wolniej niż w przypadku socjologii i przez wiele lat opierał się głównie na pracach pojedynczych autorów, takich jak np. Ithiel de Sola Pool. Badania podkreślające rolę nieformalnych i poziomych struktur interakcji zdobyły większą popularność dopiero wraz z powstaniem prac z zakresu psychologii politycznej, analizujących wpływ małych sieci społecznych na zachowania wyborcze. Kluczowymi reprezentantami tego nurtu badań byli m.in. Paul Lazarsfeld oraz Bernard Berelson (Huckfeldt, 2014, s. 46)

Dalszy rozwój podejścia sieciowego obejmował zarówno badania dotyczące problematyki decentralizacji oraz zarządzania sieciowego (analizowane m.in. 
przez Davida Marsha i Rodericka A.W. Rhodesa (zob. Rhodes, Marsh, 1996, s. 210-222), jak również mechanizmy funkcjonowania sieci patronażu i korupcji (opisywane m.in. przez Thomasa Guterbocka (zob. Guterbock, 1980). Ważnym impulsem w procesie adaptacji perspektywy sieciowej do badań politologicznych był rozwój teorii podkreślających wpływ nieformalnych sieci społecznych na funkcjonowanie instytucji politycznych, który zapoczątkowały m.in. prace Roberta Putnama (Lazer, 2011, s. 61). Prawdziwą rewolucję popularyzującą badania sieciowe przyniosło jednak dopiero pojawienie się i upowszechnienie Internetu, którego sieciowa konstrukcja wpływa obecnie na wszystkie aspekty funkcjonowania rzeczywistości społeczno-politycznej. Za pomocą nowej perspektywy analizowana jest zarówno cyfryzacja tradycyjnych obszarów badań politologicznych (takich jak funkcjonowanie ruchów społecznych), jak również powstawanie zupełnie nowych zjawisk i procesów społeczno-politycznych, np. e-government (zob. Carrizales, 2004, s. 130-139).

Reasumując, historia i rozwój perspektywy sieciowej wskazuje kilka możliwych przyczyn powstawania trudności w pełnym wykorzystaniu jej możliwości w obszarze badań politologicznych, które zostaną rozwinięte w dalszej części artykułu:

1. problemy wynikające $z$ konieczności przystosowania zestawu narzędzi badawczych powstałych i rozwijanych w obszarze innej dziedziny nauki - socjologii,

2. problemy wynikające z braku powszechnej zgody teoretyków co do pozycji perspektywy sieciowej w strukturze metodologii badań politologicznych (poziom metody czy paradygmatu),

3. problemy wynikające $\mathrm{z}$ różnorodności przedmiotów badań, do których stosowana bywa analiza sieci, bez odpowiedniej oceny ich wpływu na proces realizacji badań.

Mając na uwadze te ograniczenia, autorzy dokonają syntezy podstawowych założeń omawianej perspektywy sieciowej, która będzie obejmować zarówno próbę jej definicji, jak i oceny jej przydatności w kontekście badań nad procesem formowania koalicji gabinetowej. 


\section{PODSTAWOWE ZAŁOŻENIA PERSPEKTYWY SIECIOWEJ}

Badania realizowane z wykorzystaniem perspektywy sieciowej charakteryzują się przenikaniem założeń paradygmatów strukturalistycznego i behawioralnego. Świadczą o tym dwie cechy, które można uznać jako konstytutywne dla definicji tej perspektywy:

- postrzeganie jednostki jako funkcjonującej nieautonomicznie - koncentracja uwagi badacza na szerszych strukturach warunkujących jej oddziaływanie,

- rozszerzanie badań nad formalnymi, hierarchicznymi strukturami społecznymi o nieformalne, poziome relacje współwarunkujące funkcjonowanie istniejącego porządku społecznego (w tym politycznego) (Knoke, 2003, s. 107-108).

$\mathrm{W}$ tak rozumianej perspektywie badawczej akcentuje się relacje wymiany zasobów oraz komunikację zachodzącą pomiędzy aktorami w sieci. Zgodnie z tym opisem cytowany wcześniej Wellman wskazuje, że zakorzenienie badań sieciowych w dwóch różnych paradygmatach prowadzi do powstania dwóch orientacji wewnątrz omawianej perspektywy:

- orientacji formalistycznej - skupiającej się na topologii sieci oraz powtarzających się wzorach istniejących interakcji,

- orientacji strukturalistycznej - skupiającej się na formułowaniu przewidywań dotyczących szerszego oddziaływania sieci, opisywanej jako struktura nieredukowalna do prostej sumy składających się na nią części (Wellman, 1983, s. 160).

Pomimo tej wewnętrznej różnorodności badania prowadzone zgodnie z założeniami perspektywy sieciowej charakteryzują się wyraźnym przejściem z opisów kategorialnych, bazujących na atrybutach badanych jednostek, do opisów relacjonalnych, obrazujących dynamikę interakcji zachodzących w obrębach opisywanych struktur. W takim opisie aktorzy i ich interakcje postrzegani są jako nierozerwalnie splecione ze sobą fenomeny. Przejście to wynika z odmiennego sposobu postrzegania interakcji społecznych oraz specyficznego użycia technik pomiarowych, odchodzących od narzędzi typowych dla statystyki na rzecz narzędzi umożliwiających badanie dynamiki struktur połączeń (Wellman, 1983, s. 170). 


\section{METODY I TECHNIKI BADAŃ SIECIOWYCH}

Specyficzny charakter badań sieciowych decydujący o możliwości wyróżnienia osobnej perspektywy badawczej ujawnia się na każdym etapie procesu badawczego:

1. etapie zbierania informacji oraz określenia podstawowych mierników,

2. etapie systematyzowania badań oraz pogłębionej analizy,

3. etapie tworzenia konkluzji oraz prezentacji wyników badań.

Schemat badań realizowanych według perspektywy sieciowej różni się w zależności od przedmiotu badań oraz dziedziny nauki wykorzystującej dane badania. Dostosowanie badań sieciowych do procesu formowania koalicji gabinetowej zostanie omówione w dalszej części pracy, jednak dla precyzji wywodu również w tym miejscu przedstawione zostaną generalne różnice w procedurach badań, widoczne w obszarach badań socjologicznych oraz politologicznych.

Etap zbierania danych rozpoczyna się od szczegółowego określenia przedmiotu badań, a także wyróżnienia jego cech oraz zmiennych, które stanowić będą podstawę analizy. W badaniach socjologicznych przeprowadzanych zgodnie z założeniami perspektywy sieciowej najczęściej wybierane są te aspekty funkcjonowania struktur społecznych, które podkreślają ich niehierarchiczną budowę oraz umożliwiają ich zmatematyzowany opis bazujący na teorii grafów. Zbierane są te dane, które w procesie agregacji ujawniają powtarzające się schematy, tworzące wzorce zachowań. W ich pomiarze wykorzystuje się metody i techniki zarówno badań jakościowych, jak i ilościowych, do których można zaliczyć kwestionariusze osobowe, ankiety, wywiady (w tym np. wywiad narracyjny, wywiad swobodny ze standaryzowaną listą poszukiwanych informacji oraz zogniskowany wywiad grupowy), a także rejestry aktywności wybranych jednostek, które tworzone są przy użyciu inwigilacyjnych możliwości nowych technologii informacyjno-komunikacyjnych. Takie pomiary dostarczają danych o charakterze ilościowym, jak i jakościowym, które cechują się szczegółowością oraz dogłębnością, co pozwala na wnikliwą analizę bliskości i złożoności relacji pomiędzy aktorami w sieci.

W analizach politologicznych realizowanych według założeń perspektywy sieciowej tylko część badań można wykonać za pomocą wskazanych wyżej narzędzi badawczych. Wiąże się to m.in. z silną hierarchizacją struktur politycznych - niektóre obszary badań politologicznych dotyczą tylko wąskiego obszaru funkcjonowania elit politycznych, co uniemożliwia określenie uśrednionych jednostek badawczych, bądź też próby reprezentatywnej dla szerszej zbiorowości. 
Odmienne są nie tylko metody, ale też źródła pozyskiwanych danych. Informacje dotyczące klasy politycznej oraz sieciowych relacji zachodzących wewnątrz niej pochodzą często z doniesień prasowych i nierzadko mają niepełny charakter. Wymusza to prowadzenie badań o charakterze mieszanym, bądź też jakościowym. Zmiana charakteru badań wiąże się z problemem interpretacji zdobytych informacji, co wynika po pierwsze z zastosowania specjalistycznego „języka politycznego" (funkcjonalnego typu języka ogólnego) (Trysińska, 2004, s. 9), po drugie z problemu wiarygodności informacji dostępnych w mediach.

Etap systematyzacji zgromadzonych danych oraz bezpośredniej analizy w przypadku badań socjologicznych polega głównie na opracowywaniu modeli zachodzących wewnątrz sieci interakcji, z uwzględnieniem kierunków ich oddziaływania, a także kanałów komunikacji oraz rodzaju zasobów przepływających w sieci. Za pomocą miar wskazujących na częstość oraz częstotliwość interakcji przeprowadzana jest analiza:

- połączeń - ich dystrybucji, przepływowości, scentralizowania, grupowania, spójności oraz schematów rozgałęzień,

- pozycji jednostki (lub grupy) w sieci - jej centralności (odległości od centrum sieci), liczby oraz charakteru dostępnych dla niej powiązań,

- relacji diadycznych (pomiędzy dwoma aktorami) - spójności (wynikającej z dystansu pomiędzy wybranymi aktorami oraz ilością i rodzajem istniejących połączeń) oraz wzajemnej równoważności (w jakim stopniu badani aktorzy pełnią w sieci podobną rolę) (Borgatti, Mehra, Brass, Labianca, 2009).

W badaniach politologicznych przeprowadzonych zgodnie z założeniami perspektywy sieciowej analiza również jest skoncentrowana na badaniu takich cech, jak: centralność zachodzących interakcji, ich wzajemność oraz bliskość. Różnica w stosowanych procedurach badawczych wynika jednak z użycia „mieszaniny” danych jakościowych oraz ilościowych opracowywanych nie tylko przy pomocy metod statystycznych, ale także takich metod jak analiza zawartości (content analysis) (zob. Pisarek, 1983, s. 45). Użycie mniej precyzyjnych danych jakościowych prowadzi do analizy spekulatywnej, podkreślającej przewagę znaczenia aspektów kontekstualnych nad usystematyzowanymi operacjami liczbowymi, dominującymi w klasycznej SNA.

Na poziomie formowania wniosków oraz prezentacji rezultatów badań w socjologii używane są socjogramy pozwalające na graficzną reprezentację relacji zachodzących pomiędzy badanymi jednostkami. Kształt tych reprezentacji jest wynikiem dalszego opracowania uzyskanych pomiarów statystycznych 
przy użyciu szerokiego wachlarza oprogramowania komputerowego takiego jak Ucinet czy Gephi. Formowanie wniosków płynących z tak wytworzonych modeli dotyczy głównie wpływu, jaki nieformalne i poziome sieci powiązań wywierają na zachowanie pojedynczych jednostek, a także ewentualnych trendów dotyczących przyszłych przekształceń samej sieci.

W przypadku badań politologicznych sposób opracowywania socjogramów wynika z bardziej złożonego procesu identyfikacji podstawowych aktorów sieci oraz podstawowych kanałów komunikacyjnych, dokonywanych na podstawie analizy danych jakościowych. Brak ukierunkowania na dane statystyczne nie zmniejsza znaczenia badania samej sieci, której analiza polega jednak na bardziej domyślnym i mniej automatycznym procesie formułowania hipotez odnośnie najważniejszych trendów zachodzących $\mathrm{w}$ wielomodalnych sieciach politycznych.

\section{ZASADNOŚĆ WYKORZYSTANIA PERSPEKTYWY SIECIOWEJ W BADANIACH NAD PROCESEM FORMOWANIA KOALICJI GABINETOWYCH}

Formowanie koalicji gabinetowej jest jednym z najistotniejszych procesów politycznych we współczesnych demokracjach liberalnych, charakterystycznym zwłaszcza dla reżimów parlamentarno-gabinetowych ${ }^{3}$, w których egzystencja rządu uzależniona jest od poparcia większości deputowanych w legislatywie. Ponieważ w wyniku wyborów bardzo rzadko jedno ugrupowanie zdobywa taką liczbę miejsc w parlamencie, która pozwalałaby na samodzielne sformowanie gabinetu, niezbędne zazwyczaj jest rozpoczęcie przetargów koalicyjnych, których celem jest stworzenie trwałego sojuszu rządowego.

Badania nad procesem formowania koalicji gabinetowych prowadzone są w dwóch nurtach - logiczno-matematycznym i empirycznym (Antoszewski, 2008, s. 344-347). Pierwszy z nich nawiązuje do teorii gier i bazuje na wyliczeniach prowadzonych w oparciu o arytmetykę parlamentarną. W podejściu tym kluczowe pytanie dotyczy warunków, jakie powinna spełniać koalicja, aby

\footnotetext{
${ }^{3} \mathrm{~W}$ niniejszym artykule przyjęto wąskie znaczenie terminu reżim polityczny, określające go jako ogół norm regulujących stosunki między władzą ustawodawczą (parlamentem) a wykonawczą (rządem) , a także pomiędzy poszczególnymi elementami egzekutywy. W tym znaczeniu pojęcie reżimu politycznego stosowane jest zamiennie z terminami system lub forma rządu (Antoszewski, 1999, s. 98).
} 
uformowany przez nią gabinet był trwały (Antoszewski, 2008, s. 344).W związku z tym koncepcje tworzone $\mathrm{w}$ ramach tego nurtu nie opisują warunków i motywacji, jakie faktycznie skłoniły partie do współpracy, a raczej przedstawiają najbardziej prawdopodobny skład trwałego sojuszu i z tego względu nazywane są predyktywnymi teoriami koalicji (Havlik, Kopeček, 2009, s. 60).

Drugie z wymienionych podejść - nurt empiryczny - rozwinęło się w Europie jako wyraz krytyki ustaleń dokonywanych w ramach nurtu nawiązującego do teorii gier. $Z$ tego względu uogólnienia tworzone na kanwie podejścia empirycznego opierają się głównie na podstawie analizy faktycznie funkcjonujących koalicji, a nie na interpretacji abstrakcyjnych modeli logiczno-matematycznych. Podstawowe założenia nurtu empirycznego w badaniach nad koalicjami gabinetowymi przedstawił Andrzej Antoszewski, który zaliczył do nich m.in. ujmowanie koalicji gabinetowych jako jednego z komponentów procesu politycznego; uwzględnianie wpływu wielu czynników warunkujących tworzenie i utrzymanie koalicji, wśród których szczególne znaczenie posiada mechanizm systemu partyjnego; użycie analizy porównawczej obejmującej możliwie dużą liczbę przypadków i możliwie długi okres; podkreślenie wewnętrznej złożoności koalicjantów (partii politycznych), wynikającej z ich struktury organizacyjnej, konfliktów wewnętrznych, podziałów na frakcje, rozłamów oraz powstających na ich tle odmienności stanowisk co do potencjalnych sojuszy; oraz akcentowanie znaczenia powiązań nieformalnych lub częściowo sformalizowanych, do których zaliczyć można np. udzielanie zewnętrznego poparcia (Antoszewski, 2008, s. 346).

Perspektywa sieciowa, opisana w poprzednich częściach niniejszego artykułu, jako ujęcie badawcze przystaje do założeń nurtu empirycznego. Jej zastosowanie w rozważaniach nad koalicjami gabinetowymi, będące skądinąd rozszerzeniem dotychczas wykorzystywanego katalogu metod badawczych, wydaje się uzasadnione i korzystne z co najmniej trzech powodów.

Po pierwsze, partie polityczne będące głównymi uczestnikami koalicji są w rzeczywistości sieciami zarówno pojedynczych polityków, jak i mniej lub bardziej sformalizowanych frakcji wewnątrzpartyjnych. Taką tezę potwierdzają ustalenia m.in. Nelsona Polsby’ego i Mildred Schwartz, którzy w swoich rozważaniach wypracowali sieciowe definicje partii politycznych, według których są to sieci różnorodnych podmiotów działających zarówno wewnątrz formalnych struktur, jak i poza nimi (uwypukla się wówczas dwa rodzaje członkostwa: formalne i nieformalne, które odnoszą się do całej rzeszy mniej lub bardziej zagorzałych „sympatyków” danej partii) (zob. Reichley, 2000, s. 111; Schwartz, 1990, 
s. 10, za: Parigi, Sartori, 2014, s. 55). Takie podejście jest zgodne z założeniami nurtu empirycznego oraz z opinią Karla von Beyme, który poddając krytyce orientację ujmującą partie jako monolitycznych aktorów, wskazał na istotne znaczenie, jakie $\mathrm{w}$ funkcjonowaniu partii mają relacje interpersonalne oraz nieformalne powiązania pomiędzy frakcjami (Beyme, 1985, s. 320, za: Jednaka, 2004, s. 22). Prostą implikacją powyższych ustaleń jest stwierdzenie, że również koalicje gabinetowe, będące formą kooperacji pomiędzy partiami, powinny być traktowane jako sieci wzajemnie oddziałujących na siebie podmiotów. $\mathrm{Z}$ tego względu wykorzystanie perspektywy sieciowej w badaniach nad procesem formowania koalicji gabinetowych należy uznać za pomocne i zrozumiałe.

Po drugie, wykorzystanie perspektywy sieciowej w badaniach nad procesem tworzenia sojuszu rządowego jest uzasadnione istotą przetargów koalicyjnych stanowiących proces, w którym aktorzy chcący zawrzeć sojusz rządowy angażują się w komunikację w celu znalezienia wzajemnie korzystnego porozumienia. Ich rozpoczęcie jest niezbędne wówczas, gdy: dla każdej z negocjujących stron istnieją takie korzyści, które mogą być osiągnięte jedynie w wyniku kolektywnego działania; istnieje wiele różnych sposobów dystrybucji korzyści związanych z tym działaniem; oraz żaden aktor nie może narzucić negocjującym stronom warunków porozumienia (Lupia, Strøm, 2012, s. 59). Liderzy partii politycznych angażują się w proces przetargów koalicyjnych, ponieważ chcą zarówno zdobyć określone stanowiska rządowe, jak również zrealizować głoszone przez siebie postulaty programowe (zob. Jednaka, 2004, s. 36). Zachowując się w sposób racjonalny, w trakcie przetargów przedstawiciele partii będą zawsze dążyć do maksymalizacji potencjalnych korzyści. Ich zyski są jednak uzależnione od posiadanych zasobów, które wnoszone są do powstającego sojuszu i których wymiana następuje podczas procesu komunikacji w trakcie przetargów koalicyjnych. Podstawowym zasobem jest w tym przypadku liczba posiadanych mandatów w parlamencie, jednak należy do nich zaliczyć również pozycję na arenie politycznej (np. czy dana partia jest jednym możliwym koalicjantem), poparcie określonych grup społecznych, czy też zaplecze fachowe i pozapartyjne. Reasumując, przetargi koalicyjne, opierające się na interakcjach oraz wymianie zasobów pomiędzy negocjującymi aktorami, stanowią idealny przedmiot badań wykorzystujących perspektywę sieciową, rozpatrujących liczbę oraz typ uczestników procesu komunikacji, ich wzajemne powiązania, a także dynamikę zachodzących pomiędzy nimi relacji.

Po trzecie, wykorzystanie perspektywy sieciowej jest również uzasadnione złożonością i wielopoziomowością tworzenia sojuszu rządowego. W procesie tym 
bierze udział wiele różnego rodzaju podmiotów, które negocjując ze sobą, wymieniają się posiadanymi zasobami, tworząc i wykorzystując wiele różnorodnych powiązań, w tym również tych nieformalnych. Ze względu na dążenie do jak najlepszego wykorzystania wszystkich zasobów i maksymalizacji potencjalnych korzyści, powiązania tworzone i wykorzystywane w procesie zawiązywania koalicji gabinetowej mogą mieć różny zasięg i być wielokrotnie złożone. $Z$ tego względu, choć formalnie w przetargach koalicyjnych uczestniczą zazwyczaj tylko liderzy partyjni, to w rzeczywistości na proces ten mogą oddziaływać również aktorzy z różnych poziomów - zarówno z centralnego, odnoszącego się do elity partyjnej, jak i peryferyjnego, związanego ze strukturami regionalnymi, czy też globalnego, odnoszącego się do podmiotów formalnie pozostających poza strukturą partyjną, jednak aktywnie oddziałujących na politykę wewnętrzną danego ugrupowania (są to np. organizacje i podmioty wspierające daną partię, jej zaplecze fachowe oraz inni istotni sympatycy). W związku z powyższym wykorzystanie analizy sieci, w której kładzie się nacisk na badanie relacji pomiędzy poszczególnymi podmiotami określanymi jako aktorzy uwikłani w sieć (Batorski, 2008, s. 167), okazuje się zasadne i bardzo pomocne w lepszym zobrazowaniu i interpretacji wszystkich powiązań, również tych ukrytych i nieformalnych, pomiędzy różnorodnymi uczestnikami wielopoziomowego procesu formowania koalicji gabinetowej.

\section{MOŻLIWOŚCI I TRUDNOŚCI ZWIAZZANE Z WYKORZYSTYWANIEM PERSPEKTYWY SIECIOWEJ}

Reasumując powyższe rozważania, należy uznać, że zastosowanie perspektywy sieciowej w badaniach nad procesem formowania sojuszy rządowych jest zasadne i wiąże się z wieloma możliwościami. Perspektywa sieciowa oraz związane z nią narzędzia pozwalają bowiem na: szczegółowe rozpatrzenie liczby i typów uczestników biorących udział w procesie tworzenia koalicji gabinetowej, zdobycie wiedzy o sposobach komunikacji oraz wymianie zasobów (w tym ich rodzaju) pomiędzy negocjującymi aktorami, przeanalizowanie i interpretację formalnych i nieformalnych powiązań pomiędzy uczestnikami procesu, a także zobrazowanie wielopoziomowości procesu formowania koalicji gabinetowej.

Niestety, choć wykorzystanie perspektywy sieciowej w badaniach nad procesem tworzenia sojuszy rządowych daje wiele możliwości i korzyści, to jednak jej stosowanie związane jest również z kilkoma problemami, które dotyczą głównie 
trudności w zdobyciu szczegółowych i wiarygodnych informacji oraz braku tradycji odnoszącej się do kontekstu europejskiego.

Jak wskazaliśmy w poprzedniej części niniejszego artykułu, dane potrzebne do analizy właściwości i dynamiki relacji oraz przepływów zasobów pomiędzy aktorami uwikłanymi w sieć zdobywa się najczęściej poprzez wnikliwą obserwację oraz interpretację aktywności i postaw uwzględnianych podmiotów, a także komunikacji pomiędzy nimi. W tym celu najczęściej wykorzystuje się opisane już metody i techniki badań zarówno jakościowych, jak i ilościowych. Niestety, w odniesieniu do rozważań nad procesem formowania koalicji gabinetowej katalog możliwych do zastosowania metod badawczych jest bardzo ograniczony. Praktycznie niemożliwym jest bowiem np. przeprowadzenie ankiety wśród uczestników procesu tworzenia sojuszu rządowego, czy też zorganizowanie zogniskowanego wywiadu grupowego $\mathrm{z}$ ich udziałem. Jest to spowodowane niechęcią polityków najwyższego szczebla do uczestniczenia w tego typu przedsięwzięciach oraz poufnością procesu formowania koalicji i realiów rywalizacji politycznej.

Z powyższych względów uzyskanie odpowiednich danych potrzebnych do przeprowadzenia badań nad procesem formowania koalicji gabinetowej przy wykorzystaniu perspektywy sieciowej jest zadaniem niezwykle trudnym. W tym kontekście najprostsze i najefektywniejsze wydaje się wykorzystanie analizy treści i materiałów zastanych, do których należy zaliczyć przede wszystkim artykuły oraz wywiady publikowane w dziennikach i tygodnikach, których autorzy opisują i analizują bieżące wydarzenia polityczne oraz ujawniają ich kulisy. Niestety stronniczość mediów masowych, szczególnie w odniesieniu do relacjonowania przebiegu wydarzeń politycznych, mocno oddziałuje na wiarygodność uzyskiwanych w ten sposób danych. Z tego względu podczas analizy artykułów prasowych warto przyjąć powszechną zasadę, zastosowaną wcześniej m.in. przez Wiesławę Jednakę (zob. Jednaka, 2004, s. 8), zgodnie z którą uznaje się informację za miarodajną, jeśli ukazała się w co najmniej w dwóch, odmiennych ideologicznie czasopismach. W odniesieniu do polskiego rynku mediów za takie można uznać np. „Gazetę Wyborczą” oraz „Rzeczpospolitą”.

Jak już wcześniej wspomniano, inną istotną trudnością związaną z wykorzystaniem perspektywy sieciowej w analizach procesu formowania koalicji gabinetowej jest brak tradycji badawczej, w której rozpatrywany był kontekst europejski. Choć jednym z wymogów pracy naukowej jest jej oryginalność, to jednak posiadanie sprawdzonych wzorców ułatwia odpowiednie zaplanowanie właściwego procesu badawczego. Analizy koalicji i partii politycznych wykorzystujące perspektywę sieciową tworzone były dotychczas przede wszystkim 
w Stanach Zjednoczonych, w których ujęcie to zyskało największą popularność. Wśród nich należy wyróżnić prace wspomnianych już Polsby'ego i Schawartz oraz m.in. Casey B.K. Dominguez i Matta Grossmanna (postulujących zachowanie równowagi $\mathrm{w}$ analizie sieci poprzez podkreślanie znaczenia zarówno zewnętrznych aktorów, jak i formalnych struktur partyjnych) (zob. Dominguez, 2005; Grossmann, Dominguez, 2009), Gregory'ego Kogera, Setha Masketa i Hansa Noela (stawiających tezę, że w funkcjonowaniu partii politycznych formalny aparat jest tylko częścią rozległej sieci złożonej z grup interesu, wiernych darczyńców, pracowników, działaczy, aktywistów czy wreszcie zaprzyjaźnionych mediów) (Koger, Masket, Noel, 2009), czy też Jonathana Bernsteina (radzącego, aby nie odrzucając analizy sieci, skupić się na znaczeniu wewnątrzpartyjnych frakcji politycznych) (Bernstein, 2005).

Zasadniczą wadą prac wymienionych autorów jest to, że zawarte w nich ustalenia odnoszą się do amerykańskiej rzeczywistości politycznej i mogą nie znaleźć potwierdzenia w warunkach europejskich. $Z$ tego względu warto podkreślić znaczenie pracy Paolo Parigiego i Laury Sartori, która dotyczy nieformalnej koalicji parlamentarnej zawartej we Włoszech w latach 70. XX wieku pomiędzy Chrześcijańską Demokracją i Partią Komunistyczną i jest jedną z nielicznych prób wykorzystania analizy sieci w badaniach nad funkcjonowaniem europejskich partii politycznych (Parigi, Sartori, 2014, s. 59-62). Jeśli natomiast chodzi o polską tradycję badań nad partiami politycznymi, to niestety nie dostrzegamy w niej analiz bazujących na perspektywie sieciowej. Jak jednak wskazują Katarzyna Sobolewska-Myślik, Beata Kosowska-Gąstoł oraz Piotr Borowiec, poważna luka w literaturze przedmiotu dotyczy całego zakresu badań nad strukturami wewnętrznymi i organizacją głównych polskich partii politycznych (Sobolewska-Myślik, Kosowska-Gąstoł, Borowiec, 2010, s. 9). Z tego względu szczególne znaczenie posiada praca wymienionych autorów, w której częściowo zrealizowano założenia perspektywy sieciowej poprzez wykorzystanie podobnych modeli funkcjonowania partii takich jak np. stratarchia Richarda Katza i Petera Maira (Sobolewska-Myślik i in., 2010, s. 29).

Reasumując, opisana w poprzednich akapitach tradycja badań wykorzystujących perspektywę sieciową do analizy funkcjonowania partii politycznych wskazuje, że w literaturze przedmiotu na próżno szukać sprawdzonych wzorców wskazujących, w jaki sposób zastosować ujęcie sieciowe w badaniu procesu formowania koalicji gabinetowej. $Z$ tego względu każdy badacz chcący tego dokonać będzie musiał wypracować całkowicie oryginalne i nowatorskie sche- 
maty, których zasadność weryfikowana będzie w trakcie prowadzonych badań i dokonywanych analiz.

\section{ZAKOŃCZENIE}

Poniższy artykuł stanowi w dużej mierze podsumowanie oraz uzupełnienie badań przeprowadzonych przez autorów w innym miejscu (zob. Banaś, Zieliński, 2015), jednak zawarte tu rozważania metodologiczno-teoretyczne potwierdzają przypuszczenia autorów, że perspektywa sieciowa może stanowić podstawę dla wartościowych badań nad formowaniem koalicji gabinetowych, nawet bez odwołania do wspomnianej wcześniejszej pracy autorów.

W artykule omówiona została historia badań sieciowych, dzięki czemu ukazano ewolucję zarówno jej podstawowych założeń, jak również zmian zachodzących w doborze oraz sposobie wykorzystywania podstawowych narzędzi badawczych. Zasadność wykorzystania perspektywy sieciowej we wskazanym obszarze badań przedstawiona była $z$ uwzględnieniem istniejących tradycji politologicznych dotyczących badań nad koalicjami gabinetowymi.

W artykule autorzy opisali specyficzny charakter badań sieciowych, który decyduje o możliwości wyróżnienia osobnej perspektywy i na który składa się:

- opis aktorów uwikłanych w sieć jako jednostek nieautonomicznych w swym funkcjonowaniu,

- skupienie wysiłków badawczych na nieformalnych, poziomych strukturach społecznych,

- opis badawczy uwypuklający komunikację oraz interakcję pomiędzy aktorami sieci, ze szczególnym znaczeniem relacji wymiany zasobów.

Zgodnie z ustaleniami autorów badania nad procesem formowania koalicji gabinetowych przy użyciu perspektywy sieciowej wpisują się w nurt empiryczny, a o ich potencjalnej przydatności może świadczyć kilka argumentów:

- partie polityczne będące głównymi uczestnikami koalicji są w rzeczywistości sieciami zarówno pojedynczych polityków, jak i mniej lub bardziej sformalizowanych frakcji wewnątrzpartyjnych,

- koalicje gabinetowe, będące formą kooperacji pomiędzy partiami, powinny być traktowane jako sieci wzajemnie oddziałujących na siebie podmiotów,

- istota przetargów koalicyjnych jest oparta na interakcjach poszczególnych polityków, ich wzajemnej komunikacji oraz wymianie zasobów, 
- złożoność procesu tworzenia sojuszu rządowego oznaczająca, że jednostki uczestniczące w procesie tworzą i wykorzystują wiele różnorodnych powiązań, $w$ tym również tych nieformalnych, zachodzących na wielu poziomach życia politycznego.

Reasumując, użycie perspektywy sieciowej jest szansą na szczegółową analizę liczby i typów uczestników biorących udział w przetargach koalicyjnych, komunikacji oraz wymianie zasobów zachodzących między nimi. Użycie perspektywy sieciowej może również pozwolić na interpretację formalnych i nieformalnych powiązań pomiędzy uczestnikami procesu oraz zobrazowanie jego wielopoziomowości.

Oczywiście pełne zaadaptowanie perspektywy sieciowej w badaniach nad procesem formowania koalicji gabinetowej wymaga wypracowania procedur oraz narzędzi umożliwiających przezwyciężenie licznych problemów metodologicznych wynikających z braku tradycji naukowych wykorzystujących to ujęcie w kontekście europejskim. Mało prawdopodobne jest natomiast przezwyciężenie drugiego zasadniczego problemu, jakim jest brak wiarygodnych informacji o aktorach biorących udział w tworzeniu koalicji rządowych, ale przeszkodę tę należy uznać za integralną część badań politologicznych, która w żadnym wypadku nie zmniejsza entuzjazmu autorów odnośnie możliwego użycia zaprezentowanej perspektywy w dalszej pracy badawczej.

\section{BibLIOGRAFIA:}

Antoszewski, A. (1999). Reżim polityczny. W: A.W. Jabłoński, L. Sobkowiak (red.), Studia $z$ Teorii Polityki (T. 1, s. 89-104). Wrocław: Wydawnictwo Uniwersytetu Wrocławskiego.

Antoszewski, A. (2008). Tworzenie i utrzymanie koalicji gabinetowych. W: A. Antoszewski, R. Herbut (red.), Demokracje zachodnioeuropejskie. Analiza porównawcza (wyd. III zmienione, s. 344-369). Wrocław: Wydawnictwo Uniwersytetu Wrocławskiego.

Banaś, M., Zieliński, M. (2015). Formowanie koalicji gabinetowych w perspektywie sieciowej. Studium przypadku sojuszu PO-PSL z 2007 roku. Wrocław: Atla 2.

Batorski, D. (2008). Metody analizy sieci i ich zastosowanie w ewaluacji. W: A. Haber, M. Szałaj (red.), Środowisko i warsztat ewaluacji (s. 167-191). Warszawa: Polska Agencja Rozwoju Przedsiębiorczości.

Bernstein, J. (2005). Party Network Research, Factions, and the Next Agenda. Pobrane z: https://www.uakron.edu/bliss/docs/state-of-the-parties-documents/Bernstein.pdf Berry, F.S., Brower, R.S., Choi, S.O., Goa, W.X., Jang, H., Kwon, M., Word, J. (2004). Three Traditions of Network Research: What the Public Management Research Agenda 
Can Learn from Other Research Communities. Public Administration Review, 64(5), 539-552. DOI: http://doi.org/10.1111/j.1540-6210.2004.00402.x.

Beyme, K. von. (1985). Political Parties in Western Democracies. Aldershot: Ashgate Publishing.

Boissevain, J. (1979). Network Analysis: A Reappraisal. Current Anthropology, 20(2), 392-394.

Borgatti, S.P., Mehra, A., Brass, D.J., Labianca, G. (2009). Network Analysis in the Social Sciences. Science, 323(5916), 892-895. DOI: http://doi.org/10.1126/science.1165821.

Carrizales, T. (2004). Research Resources: E-Government: Recent Publications. Public Performance \& Management Review, 28(1), 130-139.

Dominguez, C.B.K. (2005). Groups and the Party Coalitions: A Network Analysis of Overlapping Donor Lists. Pobrane z: http://home.sandiego.edu/ caseydominguez/ groupspartycoalitions.pdf.

Grossmann, M., Dominguez, C.B.K. (2009). Party Coalitions and Interest Group Networks. American Politics Research, 37(5), 767-800. DOI: http://doi.org/10.1177/ $1532673 X 08329464$.

Guterbock, T. (1980). Machine Politics in Transition: Party and Community in Chicago. Chicago: University of Chicago Press.

Havlik, V., Kopeček, L. (2009). Kształt i stabilność czeskich rządów: wpływ systemu partyjnego i wyborczego. Wrocławskie Studia Politologiczne, (10), 59-77.

Herbut, R. (2004). Partia polityczna. W A. Antoszewski, R. Herbut (red.), Leksykon politologii (s. 298-302). Wrocław: Atla 2.

Huckfeldt, R. (2014). Networks, Contexts, and the Combinatorial Dynamics of Democratic Politics. Political Psychology, 35, 43-68. DOI: http://doi.org/10.1111/ pops.12161.

Jednaka, W. (2004). Gabinety koalicyjne w III RP. Wrocław: Wydawnictwo Uniwersytetu Wrocławskiego.

Knoke, D. (2003). Political Networks. The Structural Perspective. New York: Cambridge University Press.

Koger, G., Masket, S., Noel, H. (2009). Partisan Webs: Information Exchange and Party Networks. British Journal of Political Science, 39(3), 633-653. DOI: http://doi. org/10.1017/S0007123409000659.

Lazer, D. (2011). Networks in Political Science: Back to the Future. PS: Political Science \& Politics, 44(1), 61-68. DOI: http://doi.org/10.1017/S1049096510001873.

Lupia, A., Strøm, K. (2012). Bargining, Transaction Costs, and Coalition Governance. W: K. Strøm, W.C. Müller, T. Bergman (red.), Cabinets and Coalition Bargaining: The Democratic Life Cycle in Western Europe (s. 51-83). Oxford: Oxford University Press.

McClurg, S.D., Lazer, D. (2014). Political networks. Social Networks, 36, 1-4. DOI: http:// doi.org/10.1016/j.socnet.2013.09.001.

Parigi, P., Sartori, L. (2014). The political party as a network of cleavages: Disclosing the inner structure of Italian political parties in the seventies. Social Networks, 36, 54-65. DOI: http://doi.org/10.1016/j.socnet.2012.07.005. 
Pisarek, W. (1983). Analiza zawartości prasy. Kraków: Ośrodek Badań Prasoznawczych.

Reichley, J.A. (2000). The Life of the Parties: A History of American Political Parties (Subsequent edition). Lanham: Rowman \& Littlefield Publishers.

Rhodes, R.A.W., Marsh, D. (1996). The Concept of Policy Networks in British Political Science: Its Development and Utility. Talking Politics, 8(3), 210-222.

Rice, S.A. (1927). The Identification of Blocs in Small Political Bodies. The American Political Science Review, 21(3), 619-627. DOI: http://doi.org/10.2307/1945514.

Schwartz, M.A. (1990). The Party Network: The Robust Organization of Illinois Republicans. Madison: University of Wisconsin Press.

Scott, J. (2011). Social network analysis: developments, advances, and prospects. Social Network Analysis and Mining, 1(1), 21-26. DOI: http://doi.org/10.1007/ s13278-010-0012-6.

Sobolewska-Myślik, K., Kosowska-Gąstoł, B., Borowiec, P. (2010). Struktury organizacyjne polskich partii politycznych. Kraków: Wydawnictwo Uniwersytetu Jagiellońskiego.

Trysińska, M. (2004). Jak politycy komunikuja się ze swoimi wyborcami? Analiza języka polityków na przykładzie rozmów prowadzonych $w$ telewizji polskiej oraz internecie. Warszawa: Dom wydawniczy Elipsa.

Turner, J.H. (2004). Struktura teorii socjologicznej. Warszawa: Wydawnictwo Naukowe PWN.

Wellman, B. (1983). Network Analysis: Some Basic Principles. Sociological Theory, 1, 155-200. 